\title{
Baseline amphibian survey and sampling of Batrachochytrium dendrobatidis in the Icaco and Hormiga valleys, Patillas, Puerto Rico
}

\author{
Norman Greenhawk, ${ }^{1}$ Sara Zlotnik, ${ }^{2}$ Lauren Margaret Billy, ${ }^{3}$ Sam Boas, and Sara Gabel ${ }^{4}$ \\ ${ }^{1}$ Tropic Ventures Research and Education Foundation, HC-63, Buzón 3879 Patillas, 00723, Puerto Rico. E-mail: greenhawk81@ \\ gmail.com. \\ ${ }^{2}$ Department of Biological Sciences, Purdue University, 915 West State Street, West Lafayette, Indiana 47907, USA. \\ E-mail: szlotnik@purdue.edu. \\ ${ }^{3}$ Vanderbilt University, 2416 Vanderbilt Pl, Nashville, Tennessee 37212, USA. E-mail: lauren.m.billy@ vanderbilt.edu. \\ ${ }^{4}$ University of Maryland, College Park, 4517 Knox Rd, College Park, Maryland 20740, USA. E-mail: sgabel1@terpmail.umd.edu.
}

\begin{abstract}
Baseline amphibian survey and sampling of Batrachochytrium dendrobatidis in the Icaco and Hormiga valleys, Patillas, Puerto Rico. Batrachochytrium dendrobatidis $(B d)$ is the pathogen responsible for chytridiomycosis, a disease implicated in amphibian population declines around the world. In Puerto Rico, $B d$ has been shown to cause mortalities in endemic anurans of the genus Eleutherodactylus. In July 2014, we conducted visual-encounter surveys and collected $143 \mathrm{Bd}$ swab samples at 10 locations in Icaco and Hormiga, two remote and understudied valleys in Patillas, Puerto Rico. We found five species of Eleutherodactylus and one species of Leptodactylus. Individuals of four species (E. coqui, E. cooki, E. richmondi, and E. wightmanae) yielded either positive or equivocal results for $B d$, but $93.7 \%$ of the samples tested negative for $B d$.
\end{abstract}

Keywords: conservation, Eleutherodactylus cooki, Eleutherodactylus richmondi, Eleutherodactylus wightmanae, secondary-growth forests.

\begin{abstract}
Resumen
Inventario básico de anfibios y muestreo de Batrachochytrium dendrobatidis en los valles Icaco y Hormiga, Patillas, Puerto Rico. Batrachochytrium dendrobatidis $(B d)$ es el patógeno responsable de la quitridiomicosis, una enfermedad implicada en la disminución de la población de anfibios alrededor del mundo. En Puerto Rico se ha demostrado que $B d$ causa mortalidad en ranas endémicas del género Eleutherodactylus. En julio de 2014, realizamos encuestas de encuentro visual y recogimos 143 muestras para $B d$ en 10 localidades de Icaco y Hormiga, dos valles remotos y poco estudiados en Patillas, Puerto Rico. Encontramos cinco especies de Eleutherodactylus y una especie de Leptodactylus. Los individuos de cuatro especies (E. coqui, E. cooki, E. richmondi y E. wightmanae) dieron resultados positivos o ambiguo para $B d$, pero $93.7 \%$ de las muestras dieron negativo para $B d$.
\end{abstract}

Received 22 October 2015

Accepted 6 December 2016

Distributed June 2017 


\begin{abstract}
Resumo
Levantamento básico de anfíbios e amostragem de Batrachochytrium dendrobatidis nos vales de Icaco e Hormiga, Patillas, Porto Rico. Batrachochytrium dendrobatidis $(B d)$ é o patógeno responsável pela quitridiomicose, uma doença envolvida em declínios populacionais de anfíbios ao redor do mundo. Em Porto Rico, foi demonstrado que $B d$ provoca mortalidade em anuros endêmicos do gênero Eleutherodactylus. Em julho de 2014, realizamos levantamentos por procura visual e coletamos 143 amostras para $B d$ em 10 localidades de Icaco e Hormiga, dois vales remotos e pouco estudados em Patillas, Porto Rico. Encontramos cinco espécies de Eleutherodactylus e uma espécie de Leptodactylus. Para indivíduos de quatro espécies (E. coqui, E. cooki, E. richmondi e E. wightmanae) obtivemos resultados positivos ou equívocos para $B d$, mas em $93,7 \%$ das amostras os resultados do teste para $B d$ foram negativos.
\end{abstract}

Palavras-chave: conservação, Eleutherodactylus cooki, Eleutherodactylus richmondi, Eleutherodactylus wightmanae, florestas secundárias.

\section{Introduction}

Amphibian populations have been declining globally for decades (Wake and Vredenburg 2008). One of the many factors driving these declines is the chytridiomycete fungus Batrachochytrium dendrobatidis $(B d)$. In Puerto Rico, $B d$ is at least partially responsible for the presumed extinction of Eleutherodactylus jasperi Drewry and Jones, 1976 and E. karlschmidti Grant, 1931 (Burrowes et al. 2008a). Other Puerto Rican species, such as E. coqui Thomas, 1966, have survived despite the continued presence of the pathogen on the island since the 1970s (Burrowes et al. 2008a). However, Bdlinked mortalities in this species have been observed in the wild (Longo et al. 2013), and coexistence with the pathogen likely is contributing to population declines (Longo and Burrowes 2010).

We conducted an amphibian survey and $B d$ testing in two remote and understudied valleys (Icaco and Hormiga) located on the privately owned forestry project "Las Casas de la Selva," in Patillas, Puerto Rico. On preliminary visits to Icaco Valley, we found E. cooki Grant, 1932 (Greenhawk 2013) and E. richmondi Stejneger, 1904 (Greenhawk and Zegarra, pers. obs.), two threatened species with limited ranges in Puerto Rico. We expected to find additional threatened endemics at these sites. This was the first time multi-species $B d$ testing had been conducted within the study area. Given that Burrowes et al. (2008b) documented the presence of the pathogen at higher elevations at Las Casas de la Selva (ca. $600 \mathrm{~m}$ a.s.l.), we expected to find $B d$ present at the study sites.

\section{Materials and Methods}

\section{Study Site}

The study site (Figure 1) is composed of two zones. "Zone I," the "Biodiversity and Water Resources Protection Zone," includes all of Hormiga Valley and part of Icaco Valley. "Zone IIA," is a mahogany plantation in Icaco Valley; until the late 1970s, the land was used as coffee plantation. The secondary forests (Figure 2) and mahogany plantation in the valleys are about 30 years old, and are classified as subtropical wet forest by the Holdridge Life Zone classification system (Kumme and Briscoe 1963).

\section{Visual-encounter Surveys and $\mathrm{Bd}$ Testing}

We conducted visual-encounter surveys and collected skin swabs for $B d$ detection at 10 survey points (labeled A-J) in the valley. Points A-G are located in Icaco Valley and points $\mathrm{H}-\mathrm{J}$ 


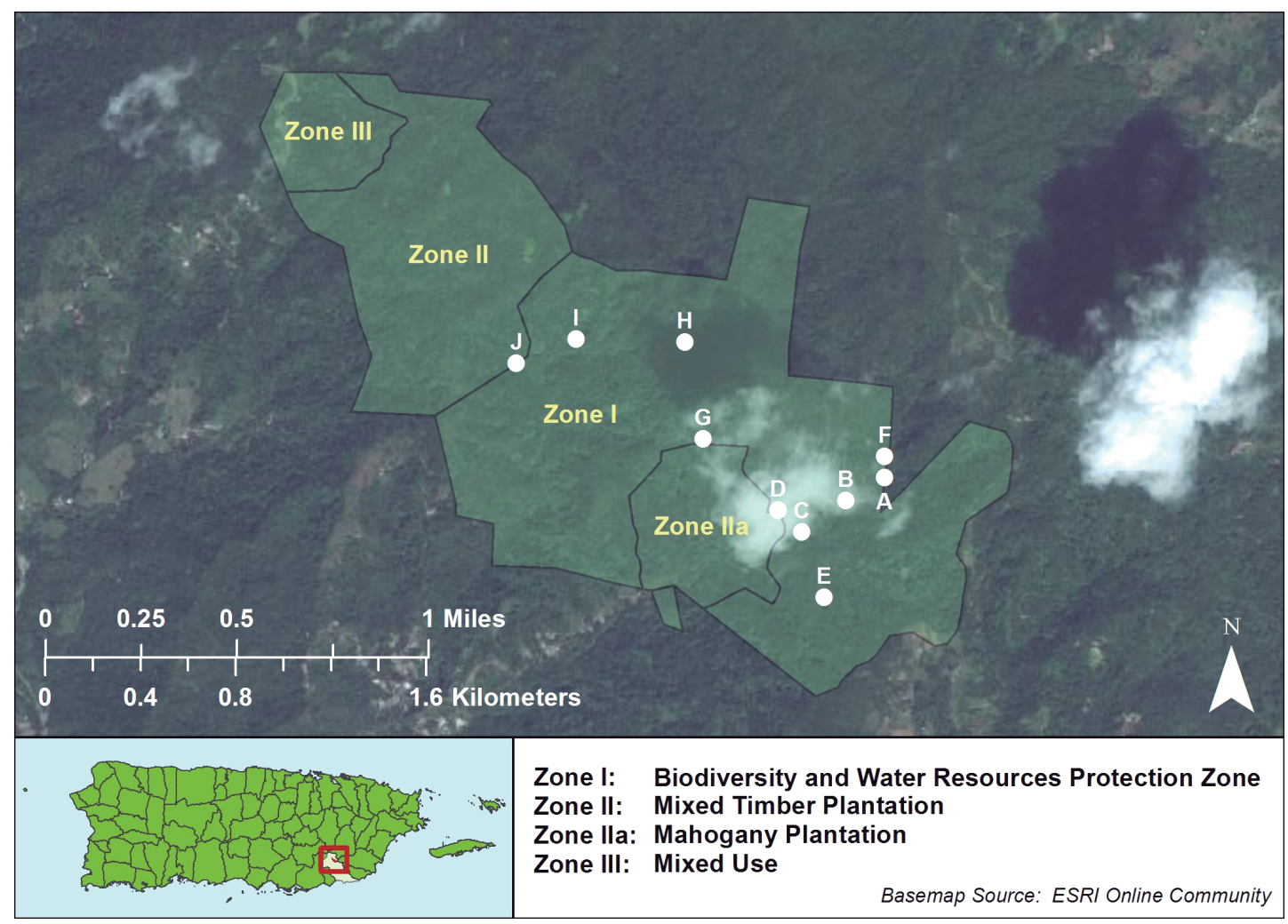

Figure 1. Map of Las Casas de la Selva, Puerto Rico. Zone I and Zone Ila constitute the survey area. Credit: Patty Ruback.
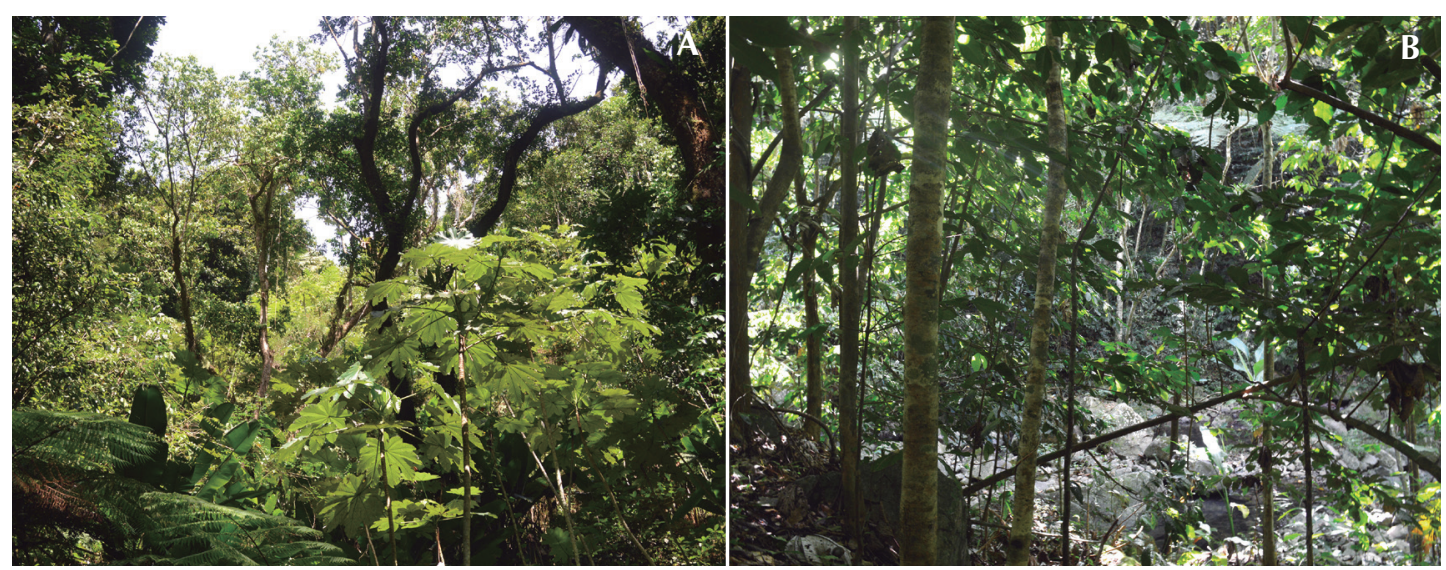

Figure 2. Typical forest of (A) Icaco Valley and (B) Hormiga Valley. 
are in Hormiga Valley (Table 1, Figure 1). We completed all surveys between 17:00 and 22:00 h. Temperature and humidity levels were recorded with a Kestrel 3000 hand-held weather meter. The mean air temperature was $25.5^{\circ} \mathrm{C}$ and humidity was $94 \%$ during the survey.

Searches were conducted at night. We wore nitrile gloves that we changed between capturing every frog by hand. Each individual was placed in new $16.5 \mathrm{~cm}$ long resealable "Ziploc" plastic bag. Species identification and $B d$ sampling were completed either in the field or at the base camp the following morning, depending on weather, safety concerns, and the number of frogs. If the anurans had to be swabbed at a location other than the site at which they were captured, they were maintained in a shaded, cool environment before being returned and released at the point of capture.

We wore nitrile gloves while swabbing, and changed gloves between each frog to reduce the risk of cross-contamination of both samples and frogs. Eight regions of the frogs were swabbed five times each: the belly, throat, undersides of forearms, undersides of legs, and sides of the body (Brem et al. 2007). Each swab was placed in a separate vial, sealed, labeled, and sent on ice to the Amphibian Disease Laboratory at the San Diego Zoo for analysis. Due to limited resources, we focused $B d$ testing on species with an IUCN status of "Vulnerable" or higher (Table 2). The exception was Eleutherodactylus coqui, which was also tested as a control, due to its abundance and its inclusion as a target species in Burrowes et al. (2008b). A total of $143 B d$ samples were collected.

\section{Results}

Six species of anurans were identified during the survey (Figure 3, Table 2). Animals tested in both Icaco and Hormiga valleys were largely free of $B d$. At least one individual from each of the four species swabbed (E. coqui, E. cooki, E. richmondi, and E. wightmanae Schmidt, 1920) tested positive for $B d$. However, $93.7 \%$ of all sampled frogs tested negative (Table 3 ).

\section{Discussion}

This survey provides baseline information about species richness and the presence of $B d$ in previously unstudied populations of threatened endemic species of Puerto Rican frogs. Three of the six frog species encountered during the survey have an IUCN status of "Vulnerable" or higher. The low occurrence of $B d$ observed may suggest that chytridiomycosis currently is not a major threat to the anuran populations in Icaco and Hormiga. Populations of Eleutherodactylus coqui in El Yunque National Forest have been shown to survive in spite of infection (Burrowes et al. 2008a). However, $B d$ infection is highly seasonal in E. coqui (Longo et al. 2010); it is possible that the low infections we found are correlated with prevailing environmental conditions.

Most studies on the Puerto Rican herpetofauna have been in the Luquillo Mountain Range (Rios-Lopez 2002). Only $7.2 \%$ of the land area of Puerto Rico is protected (Joglar et al. 2007). With such a minute amount of land under official protection, information on populations of amphibians on privately owned lands, as well as the incidence of $B d$ among those populations, is necessary to develop effective conservation management strategies. Surveys of remote, understudied areas around the island will lead to an increased knowledge of anuran biodiversity and $B d$ prevalence in Puerto Rico.

Steep topography and inclement weather prevented us from surveying the entirety of either valley. Additional surveys and $B d$ sampling events are recommended in both the wet and dry seasons to determine possible seasonal fluctuations in prevalence and infection intensity, as well to expand the total area surveyed. Acoustic monitoring research may also assist with confirming the presence of additional species. A population monitoring program should be developed for threatened species such as Eleutherodactylus cooki, E. wightmanae, and E. richmondi. 
Table 1. Visual encounter survey and $B d$ sampling point locations.

\begin{tabular}{lcccc}
\hline Survey Point & Coordinates & Elevation (m a.s.I.) & Date & Valley \\
\hline A & $18^{\circ} 03.973^{\prime} \mathrm{N}, 66^{\circ} 00.936^{\prime} \mathrm{W}$ & 359 & 19 July 2014 & Icaco \\
B & $18^{\circ} 03.920^{\prime} \mathrm{N}, 66^{\circ} 01.024^{\prime} \mathrm{W}$ & 354 & 19 July 2014 & Icaco \\
C & $18^{\circ} 03.849^{\prime} \mathrm{N}, 66^{\circ} 01.124^{\prime} \mathrm{W}$ & 321 & 19 July 2014 & Icaco \\
D & $18^{\circ} 03.898^{\prime} \mathrm{N}, 66^{\circ} 01.178^{\prime} \mathrm{W}$ & 346 & 21 July 2014 & Icaco \\
E & $18^{\circ} 03.701^{\prime} \mathrm{N}, 66^{\circ} 01.073^{\prime} \mathrm{W}$ & 356 & 26 July 2014 & Icaco \\
F & $18^{\circ} 04.075^{\prime} \mathrm{N}, 66^{\circ} 00.892^{\prime} \mathrm{W}$ & 436 & 27 July 2014 & Icaco \\
G & $18^{\circ} 04.061^{\prime} \mathrm{N}, 66^{\circ} 01.347^{\prime} \mathrm{W}$ & 473 & 28 July 2014 & Icaco \\
H & $18^{\circ} 04.279^{\prime} \mathrm{N}, 66^{\circ} 01.388^{\prime} \mathrm{W}$ & 308 & 3 August 2014 & Hormiga \\
I & $18^{\circ} 04.286^{\prime} \mathrm{N}, 66^{\circ} 01.635^{\prime} \mathrm{W}$ & 540 & 5 August 2014 & Hormiga \\
J & $18^{\circ} 04.232^{\prime} \mathrm{N}, 66^{\circ} 01.771^{\prime} \mathrm{W}$ & 374 & 5 August 2014 & Hormiga \\
\hline
\end{tabular}

Table 2. Encountered amphibians. *As of 11/27/2016, per www.IUCNredlist.org.

\begin{tabular}{lccc}
\hline Encountered species & IUCN Status* & \multicolumn{2}{c}{ Number Captured } \\
& & Icaco & Hormiga \\
\hline Eleutherodactylus brittoni & Least Concern & 7 & 23 \\
E. coqui & Least Concern & 29 & 8 \\
E. cooki & Vulnerable & 34 & 35 \\
E. richmondi & Critically Endangered & 11 & 34 \\
E. wightmanae & Endangered & 6 & 1 \\
E. spp. (unidentified juveniles) & NA & 15 & 1 \\
Leptodactylus albilabris & Least Concern & 6 & 2 \\
\hline
\end{tabular}

Table 3. $B d$ test results by species.

\begin{tabular}{|c|c|c|c|c|c|c|c|c|c|}
\hline \multirow{2}{*}{ Species } & \multirow{2}{*}{$\begin{array}{l}\text { Total Frogs } \\
\text { Sampled } \\
\text { (both valleys) }\end{array}$} & \multicolumn{4}{|c|}{ Icaco Valley } & \multicolumn{4}{|c|}{ Hormiga Valley } \\
\hline & & Positive & Equivocal & Negative & Total & Positive & Equivocal & Negative & Total \\
\hline E. coqui & 22 & 0 & 0 & 2 & 2 & 3 & 0 & 17 & 20 \\
\hline E. cooki & 41 & 1 & 1 & 31 & 33 & 0 & 0 & 8 & 8 \\
\hline E. richmondi & 38 & 0 & 0 & 11 & 11 & 1 & 0 & 26 & 27 \\
\hline E. wightmanae & 26 & 0 & 0 & 6 & 6 & 1 & 1 & 18 & 20 \\
\hline E. spp. & 16 & 1 & 0 & 14 & 15 & 0 & 0 & 1 & 1 \\
\hline Total & 143 & & & & 67 & & & & 76 \\
\hline
\end{tabular}


Greenhawk et al.
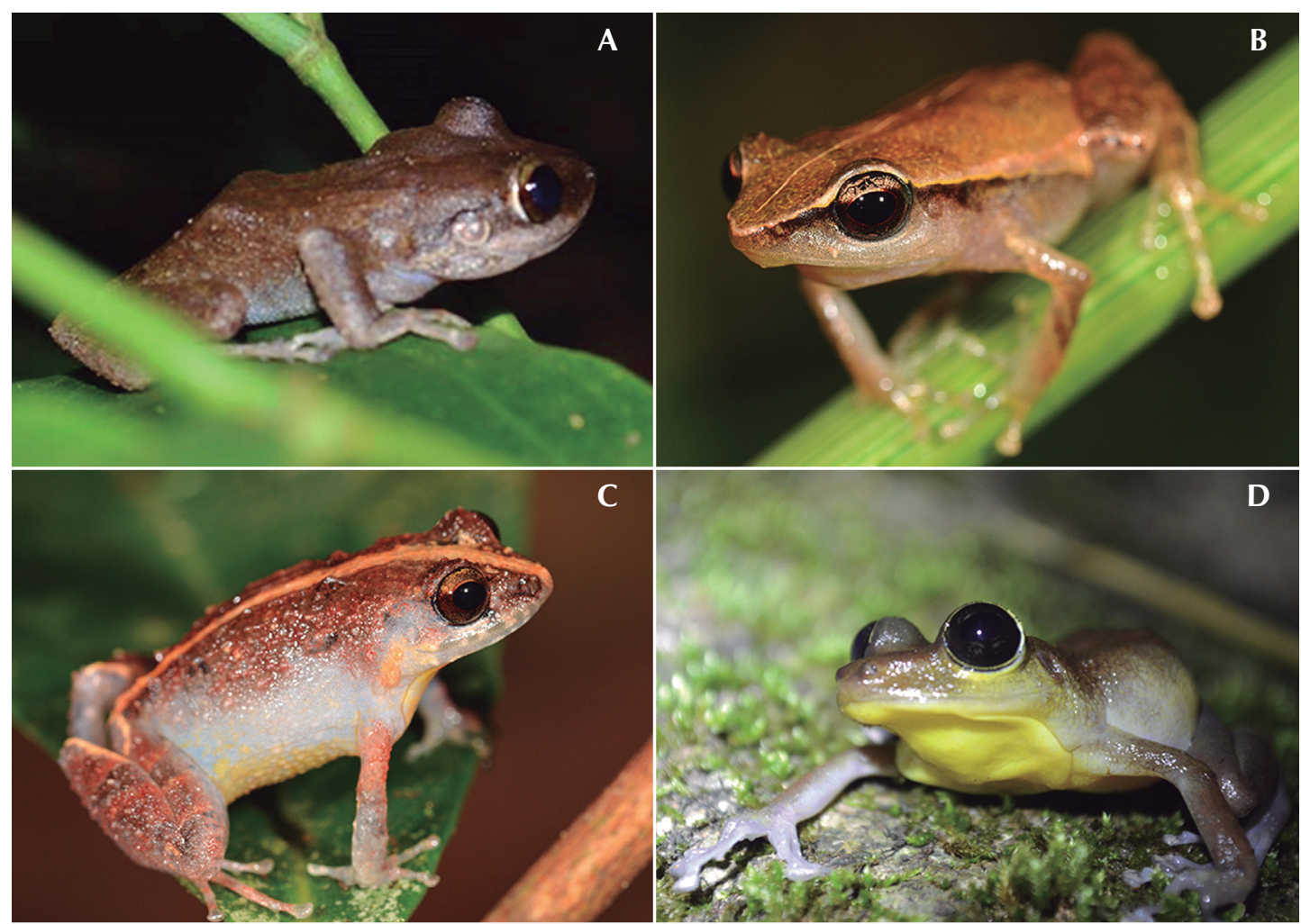

C
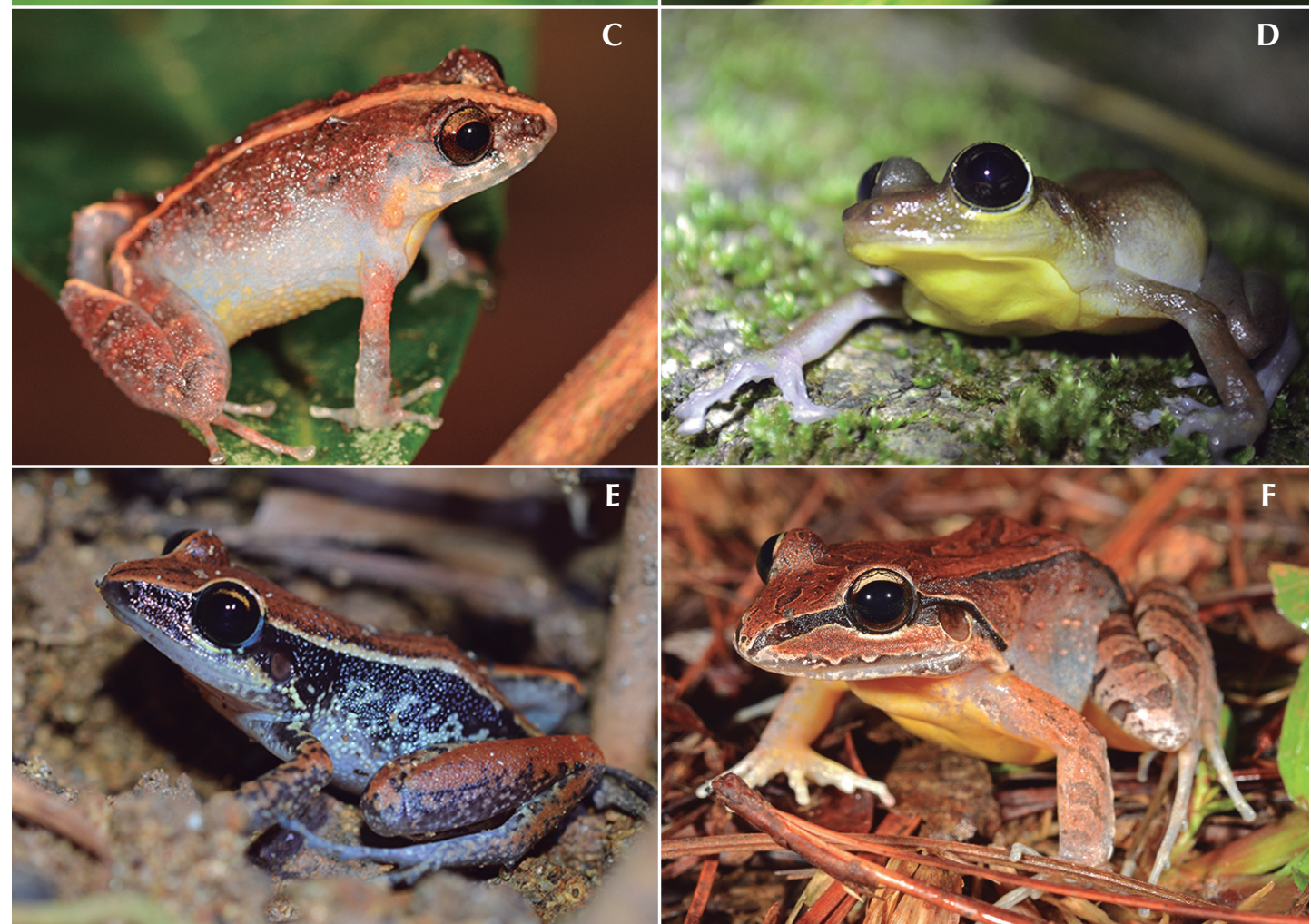

Figure 3. Anurans encountered. (A) Eleutherodactylus coqui, (B) E. brittoni, (C) E. wightmanae, (D) E. cooki, (E) E. richmondi, and (F) Leptodactylus albilabris. Photos: Gabriela Agostini (A, E), Jan Zegarra (B, C, F), Norman Greenhawk (D). 


\section{Acknowledgments}

The survey was conducted under PR DRNA permit \#2014-EPE-014, and was supported by the Mohamed bin Zayed Species Conservation Fund; Conservation, Research, and Education Opportunities International (CREOi); Earthwatch; Idea Wild; and a private donation by $\mathrm{R}$. Pesch and K. Rosskopf. We thank our field team: A. Belmonte, K. Panzier, M. Barrios Gonzalez, J. Rosado, S. Bryan, G. Agostini, A. Salas-Yoshii, J. Icaza, S. Reisburg, and S. Sridar. We also thank J. Ray of La MICA Biological Station; J. Zegarra of US Fish and Wildlife Service; J. Zimmerman, P. Burrowes, R. Cáceres, M. Alejandro-Alejandro, N. Serrano-Colón, T. Hernández Caraballo, I. Flores-Siaca, L. Laufeyson-Classen of Universidad de Puerto Rico Rio Piedras; T. Vakil and A. Rua of Tropic Ventures Research and Education Foundation; M. Nelson of the Institute of Ecotechnics; C. Martinez Rivera of the Philadelphia Zoo; Y. Haddock-Torres, and the Departmento de Recoursos Naturales y Ambientales de Puerto Rico. We thank the reviewers and editors for their time and their commentary. Photo credits J. P. Zegarra, G. Agostini, and N. Greenhawk. Figure 1 created by Patty Ruback.

\section{References}

Brem, F., J. R. Mendelson III, and K. R. Lips. 2007. FieldSampling Protocol for Batrachochytrium dendrobatidis from Living Amphibians, using Alcohol Preserved Swabs. Version 1.0 (18 July 2007). Electronic Database accessible at http://www.amphibians.org Conservation International, Arlington, Virginia, USA. Captured on 20 October 2015.
Burrowes, P. A., A. V. Longo, and C. A. Rodríguez. 2008a. Potential fitness cost of Batrachochytrium dendrobatidis in Eleutherodactylus coqui, and comments on environment-related risk of infection. Herpetotropicos 4: $51-57$.

Burrowes, P. A., A. V. Longo, R. L. Joglar, and A. A. Cunningham. 2008b. Geographic distribution of Batrachochytrium dendrobatidis in Puerto Rico. Herpetological Review 39: 321-324.

Greenhawk, N. 2013. Range extension of Eleutherodactylus cooki, the "Coqui Guajon", Grant, 1932 (Amphibia: Eleutherodactylidae). Check List 9: 10501053.

Joglar, R. L., A. O. Álvarez, T. M. Aide, D. Barber, P. A. Burrowes, M. A. García, A. León-Cardona, A. V. Longo, N. Pérez-Buitrago, A. Puente, N. Ríos-López, and P.J Tolson. 2007. Conserving the Puerto Rican Herpetofauna. Applied Herpetology 4: 327-345.

Kumme, K. W. O. and C. B. Briscoe. 1963. Forest formations of Puerto Rico. Caribbean Forester 24: 57-68.

Longo, A. V., and P. A. Burrowes. 2010. Persistence with chytridiomycosis does not assure survival of directdeveloping frogs. EcoHealth 7: 185-195.

Longo, A. V., P. A. Burrowes, and R. L. Joglar. 2010. Seasonality of Batrachochytrium dendrobatidis infection in direct-developing frogs suggests a mechanism for persistence. Diseases of Aquatic Organisms 92: 253260.

Longo, A.V., R. J. Ossiboff, K. R. Zamudio, and P. A. Burrowes. 2013. Lability in host defenses: terrestrial frogs die from chytridiomycosis under enzootic conditions. Journal of Wildlife Diseases 49: 197-199.

Rios-Lopez, N. 2002. A field guide to the reptiles and amphibians of the U.S. Naval Security Group Activity, Sabana Seca, Puerto Rico. San Juan. U.S. Naval Security Group Activity Sabana Seca, Reforesta Inc. Pp 54.

Wake, D. B. and V. T. Vredenburg. 2008. Are we in the midst of the sixth mass extinction? A view from the world of amphibians. Proceedings of the National Academy of Sciences 105: 11466-11473. 